Florida International University

FIU Digital Commons

FIU Electronic Theses and Dissertations

University Graduate School

3-28-1997

\title{
A sociological look at the Maria paradox
}

Cecilia Juana De Sola Potharst

Florida International University

Follow this and additional works at: https://digitalcommons.fiu.edu/etd

\section{Recommended Citation}

De Sola Potharst, Cecilia Juana, "A sociological look at the Maria paradox" (1997). FIU Electronic Theses and Dissertations. 2755.

https://digitalcommons.fiu.edu/etd/2755

This work is brought to you for free and open access by the University Graduate School at FIU Digital Commons. It has been accepted for inclusion in FIU Electronic Theses and Dissertations by an authorized administrator of FIU Digital Commons. For more information, please contact dcc@fiu.edu. 


\section{FLORIDA INTERNATIONAL UNIVERSITY \\ Miami, Florida}

\section{A SOCIOLOGICAL LOOK AT THE MARIA PARADOX}

A thesis submitted in partial satisfaction of the requirements for the degree of MASTER OF ARTS

IN

COMPARATIVE SOCIOLOGY

by

Cecilia Juana De Sola Potharst 
To: Arthur W. Herriott

College of Arts and Sciences

This thesis, written by Cecilia Juana De Sola Potharst, and entitled $\boldsymbol{A}$ Sociological Look at The Maria Paradox, having been approved in respect to style and intellectual content, is referred to you for judgement.

We have read this thesis and recommend that it be approved.

\author{
Dr. Betty H. Morrow \\ Dr. Hugh Gladwin \\ Dr. Stephen M. Fjellman, Major Professor
}

Date of Defense: March 28, 1997

The thesis of Cecilia Juana De Sola Potharst is approved.

\author{
Dean Arthur W. Herriot t \\ College of Arts and Sciences \\ Dr. Richard L. Campbell \\ Dean of Graduate Studies
}

Florida International University, 1997 


\begin{abstract}
OF THE THESIS
A SOCIOLOGICAL LOOK AT THE MARIA PARADOX

by

Cecilia Juana de Sola Potharst

Florida International University, 1997

Miami, Florida

Professor Stephen Fjellman, Major Professor
\end{abstract}

The Maria Paradox: How Latinas Can Merge Old World Traditions with New World Self-Esteem (1996) argues that acculturation is difficult for Hispanic women moreso that for other women, because traditional gender-roles hinder adaptation to life in the United States. While the book looks psychologically at the ideology of marianismo, I believe a sociological analysis of this ideology is helpful. I argue that the umbrella term of Hispanic should not be used because it assumes that this group is culturally homogeneous, which is not the case. Post-industrial society has changed the status quo irrevocably in such a way that everyone is affected. To believe that Latin women in general have more trouble that other women in achieving success in the United States lacks strong evidence at this time. 


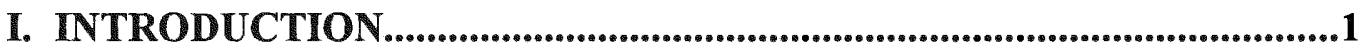

II. THE BASIC PREMISES OF THE MARIA PARADOX.........................12

Introduction to the Book............................................................................12

Why the Problem Exists................................................................................13

The Solution to the Problem is Rooted in Understanding...................14

The Basic Premises..................................................................................15

The Health of Hispanic Women................................................................16

Machismo and Marianismo Are Two Sides of the Same Coin................17

Marianismo is Perfection.......................................................................18

The Ten Commandments of Marianismo.............................................19

Acculturation is Better..............................................................................23

The Source of Successful Acculturation: Self-Esteem...........................25

Summary....................................................................................................26

III. A SOCIOLOGICAL CRITIQUE OF THE MARIA PARADOX.............27

New Roles for Hispanic Women.................................................................27

Familismo.................................................................................................29

The Marianista as Working Woman.......................................................30

Patriarchy is the Issue, Not Marianismo................................................35

Why Not Self-Esteem?............................................................................38 
TABLE OF CONTENTS (CONTINUED)

Did Marianismo Ever Really Work?....................................................39

Conclusion................................................................................................40

LIST OF REFERENCES..........................................................................44 


\section{CHAPTER 1}

\section{INTRODUCTION}

This work originated from a conference I attended on October 26, 1996. Rosa Maria Gil and Carmen Inoa Vasquez, two New York psychoanalysts, were invited to speak at the Victor E. Clark Center for Health Education about their new book, The Maria Paradox: How Latinas Can Merge Old World Traditions with New World SelfEsteem (1996). It was sponsored by the Women's Health Resource Center of Baptist Hospital. The conference also featured prominent Hispanic women from Dade County, all of whom held advanced degrees and/or occupied prestigious positions within the Miami area.

The authors suggest that the book is about empowering Hispanic women who are caught between cultural expectations and "Americanized" values. Only be resolving this dilemma can Hispanic women acculturate successfully. Gil and Vasquez argue that it is extremely difficult for Hispanic women to acculturate to North American values because Hispanic gender norms and values run counter to the norms, values, and expectations available to women in the United States at the present time. They believe the cultural clash between the Hispanic woman's previous socialization and the new cultural experience of living in present-day North America can lower their self-esteem and hinder the acculturation process for them. They argue that to successfully acculturate, the Hispanic woman must compromise and bridge a gap between her older, traditional values and the contrasting newer norms and expectations for women in the United States The 
title of the book, The Maria Paradox, refers to the idea that if a Hispanic woman behaves according to the way she has been socialized through the gender-role of marianismo, she will most likely never achieve success in the United States. They argue that there is a big difference between the traditional gender-role expectations for Hispanic women, and the current female gender-role expectations found in North America. According to the book, marianismo teaches that what is proper and appropriate to the sexes is the subservience of the female, first to her family and then to her husband. Complimentary to this is machismo, defined as the proper male gender-role ideology, which is based on the belief of male dominance and superiority.

Gil and Vasquez argue that because marianismo is actually at odds with female self-empowerment, Hispanic women are more likely to suffer from acculturation stress than other immigrants. They argue that while Hispanics are not the only groups to foster female subservience, they are the most at risk in terms of mental health. They claim that Hispanic women are the racial/ethnic group whose members are most likely to report severe depression.

After Gil and Vasquez spoke, a Puerto Rican architect asked for advice on a jobrelated problem. The ten Latin males now under her supervision resented her new promotion as their supervisor. She felt they were giving her a hard time and making it difficult for her to work in her new position. She explained that while she was brought up under the doctrine of marianismo, she has tried to empower herself and she didn't feel she had a self-esteem problem, yet but the resentment of the males working for her was causing her distress. She had already been to a therapist in order to cope with the 
situation. She was afraid to go to her superiors because she felt that if she complained, they would just find someone else to do the job. She asked the authors how she could empower herself given her situation.

Ileana Bravo, a panel member who had previously introduced herself and explained that after she read The Maria Paradox, she knew that she too was a marianista, chose to reply. Bravo said that in typical marianista fashion she did not go away to school but rather attended the University of Miami because her mother would not hear of her going away to college. After graduation she married her college sweetheart, played the dutiful wife, and later divorced her Latin and Christian husband. She involved herself in her career, married a non-Christian, "who now supports her totally and completely," and is now a reporter for a major television network in charge of current health issues. She chose to respond to the architect's question by making the following statement:

I believe I'm qualified to respond to that because I am in a very cut-throat business: journalism. I would say that those situations are now changing. I know that I have more comradeship with women and what is now happening is that we will be talking and a man will say, "oh, I guess this doesn't include me, I'll just leave you women alone..." where men actually realize women are powerful too. I would tell you to hang in there because that situation is actually changing.

Anytime people are breaking ground it is uncomfortable and no one really has an answer that is suitable to all the parties involved. However, one of the most detrimental aspects of the architect's dilemma is that the situation was not acknowledged as a legitimately serious problem and one which Bravo's idealistic and curt response only complicates. An understanding of how structural factors created the situation she is in may help her 
understand that part of her dilemma is outside of her control. However, the structural factors were largely ignored. Her problem is a social problem. Prejudice and discrimination exist, and while they may be hidden (in deference to what is the politically correct agenda of the moment), the resentment toward female emancipation continues. I don't think it is unfair to ask the question; if the promotion had gone to a white male would there be a problem? Obviously no one knows the answer to that hypothetical question, but we have enough sociological evidence to answer; probably not, because a white male doesn't disrupt the status quo.

I propose that the event cited above suggests a critical look at the premises of The Maria Paradox. It is obvious from the above discussion that more than raising the selfesteem of Hispanic women is at stake at this time, if indeed Hispanic women are less likely to succeed in the United States than other women.

The architect's problem is an excellent example of how an individual copes with and confronts structural factors in corporate America. In addition, it is about what happens when largely disenfranchised members of a society are now players in the making of a new status quo - not only players, but competitive players. Her minority status means she may face both racism and discrimination, social and institutional. How many people, choosing to focus on the assumption that she is promoted because she is a 'Hispanic and a Black and a Female,' would rather ignore her qualifications than fully accept that the competition for prestigious and well-paying positions has become fiercer? Are her employees sitting back and saying, "I'm not worried, if I don't like my new boss I'll just look for something better because there are plenty of available positions?" I don't 
think so. I believe competition in corporate America is rough enough, and leveling the playing field to accommodate all previously disenfranchised members of society is already a threat because it disrupts the status quo. When this occurs then new norms, values, and beliefs are formed. The formation of new roles for women and others, together with the creation of new norms, values and beliefs lead to the creation of new ideologies that are more equitable for all society members. As these new ideologies are being forged, there is discomfort and uneasiness for the members of any society simply because ideological changes are not easy to make or understand and are always unsettling.

The social issues involved in the architect's dilemma are new to everyone in modern post-industrial society in the sense that paid employment for all members of society is relatively new in terms of equity and fairness. The myths of patriarchy are being challenged and everyone is affected because choices have to be made about how to act, what to say, and how to think about a new situation. The architect's social class also merits consideration. Puerto Ricans, as a group, occupy the lowest positions on an economic scale, similar to Blacks rather than to Hispanics in terms of minority status. This factor alone makes her more visible in the employment arena.

The slow demise of patriarchy is an unsettling process because it calls into question long-established Western norms and values. Latin women may be facing more than they know in terms of the adaptation process. While The Maria Paradox may be a way of understanding how being Latin affects women's experiences, (we can examine how socialization under marianismo affects a woman's expectations of herself) it isn't enough if 
those experiences are not placed on a continuum of the demands a patriarchal ideology makes on all women in terms of post-industrial America.

As an individual she is an ascribed member of a minority group which has not fared well in terms of group indicators of success. Puerto Ricans, as a group, do not have outstanding rates of education, nor a great deal of upward mobility. She is not typical of her group because she holds an advanced degree. The status of architect (her own) is still largely male-dominated. As a person of color, she faces a tradition of institutionalized racism and discrimination. By not having the support of her employees, her age (I estimated mid-thirties) may be a factor in terms of not having the years of experience or the use of networks that her peers may have access to. Her situation is new for all of them, not just for her. On the societal level, post-industrial society requires that both men and women work. The 1950 s glorified the American Dream as possible with one male breadwinner. At present, for most of middle America, it takes two breadwinners and lots of innovation and creativity to come close to that ideal. So it is that the architect's problem is a good example of what occurs when such social factors as gender, ethnicity, and class interact in the modern world of paid employment without a uniform ideology based on reality rather that mythical ideals based largely on patriarchy.

How Latin women deal with the social aspects of their lives, as well as the relationship they have with themselves (the self-esteem component) is important to understand because social problems which cannot be resolved have led some scholars to argue that psychosomatic disorders can develop. It is important to note that the range of roles for women today is unlike that of any other time. In the best case scenario, within 
middle America it is now possible for women to take control and responsibility for their own lives economically, emotionally, as well as psychologically. The Maria Paradox incorporates this ideal and can help us understand the socialization of Hispanic women in terms of gender-role norms, values and expectations, which Gil and Vasquez describe as an ideology of marianismo. However, I believe that the issue of self-esteem should not be the primary concern because it focuses on the psychology of the individual rather that on the ideology of patriarchy. I believe that an increased attention to the social issues surrounding women in general is called for. We can look at the effects of race, color, class and gender on Latin females from a historical perspective. Then we can look the Latin woman as having a place on another historical continuum, one of female emancipation. The fact that this awareness is part of the nature of post-industrial society should also be explored.

In The Feminine Mystique, Betty Friedan argued convincingly about the effects an ideology based on fiction could wreak on some women. Friedan attempted to explain the psychosomatic illnesses of suburban housewives by looking at the social factors responsible in the ideology that she believed caused that kind of distress. I contend that The Maria Paradox has attempted to do the same type of analysis as did Freidan, but treats the effects of marianismo on an individual level, without examining the social components that continue to fuel it, like the enclave and the Catholic church. To do so would be to include a sociological view of the problem as well as a sociological response to it. This thesis attempts to look at The Maria Paradox form a sociological perspective by examining the book's content in the following ways: 
1. The Maria Paradox's use of the term Hispanic assumes a homogeneity among the Latin peoples based on the Spanish language. Using this term also implies that all Spanish-language origin groups are culturally homogenous. Scholars argue that neither one of these statements is correct. I believe a book geared towards Latin women should acknowledge the diverse experiences of women from Central and Latin America. Some of these differences are historical, linguistic, geographical and class-based. A look at the term's political implication is useful since the word Hispanic is used formally as an cultural identity marker. I prefer the traditional term Latin simply because people from Central and Latin America typically refer to themselves as Latinos, which is considered a much broader category by scholars and typically by Hispanics themselves. The term Latin or Latinos as is commonly used at present refers to people of Latin origins, but not necessarily in historical, political, linguistic, or economic terms.

2. There are other immigrant groups whose norms and values appear to be at odds with American cultural norms and values, but are actually much more similar than dissimilar. I argue that The Maria Paradox contributes to the belief that Hispanic women are very different from North American women. The authors of The Maria Paradox argue that Hispanic women have little in common with non-Hispanic women except for their entry in record numbers into the workforce. I argue that the differences between these two groups is actually minimal, and that their commonality lies in their struggle against the patriarchal myths that historically bound women to second class status. The Maria Paradox says marianismo is about self-sacrifice, passivity, and that it can be considered an extreme form of femininity. It claims that North American women are not 
socialized under such feminine standards. To assume that patriarchy is dead in North America, as Gil and Vasquez imply, it to assume that the control myths of patriarchy solely apply to Hispanic women. I argue that because patriarchy teaches female subservience we can assume most cultures fall under patriarchy. I argue that because the United States is undergoing the rapid changes resulting from post-industrialism, Gil and Vasquez view the multiple alternatives now available for Hispanic women as "a North American phenomenon," when in fact the technological and social options that become available daily are part and parcel of post-industrialization. Concurrent with rapid technological changes is the lack of a uniform ideology because of the emerging roles for both women and men. Immigrants who happen to enter the picture at a time when there is the demise of a uniform patriarchal ideology are going to experience crises of identity, if only because the emancipation of women and other disenfranchised groups is a relatively new phenomena. To consider that women in North America are emancipated, and that their "Latina" counterparts are only just beginning to encounter that rewarding experience is altogether quite exaggerated and simplistic.

3. The subject of immigration has always been an especially poignant one, most specifically whenever Americans perceive their lifestyle to be less than ideal. From a sociological standpoint how a group incorporates itself within the United States differs between ethnic groups and varies with local situations. Scholars argue that sometimes acculturation occurs, sometimes it doesn't. Current studies that take into account the country of origin, the immigration history of the group, the mode of incorporation into the 
United States, and the social class of the individual, help shed light on the diverse experiences of Latin women.

4. The Maria Paradox defines the concept of marianismo and argues that it has ill-effects on the well-being of Hispanic females because it acts against female empowerment. According to the Gil and Vasquez, empowerment is the ability to be critically aware of one's own circumstances and to chose to act differently in order to improve them. They assume that marianismo defies critical awareness because it teaches females to follow rather than lead, and answer rather than question their circumstances. I propose to address the following; If marianismo does exist, then what are the social implications of this ideology? Placing marianismo within patriarchy and within a sociological framework is to take it out of the realm of a strictly Hispanic psychological phenomena, and place it on an historical continuum which leads away from patriarchal ideologies and toward more equitable conditions for not only Latin women, but for all members of a society..

In summation, marianismo may cause a lowering of self-esteem and scholars agree that self-esteem is crucial to mental health. It is possible that low self-esteem hinders acculturation. However, I will argue that when discussing marianismo as a psychological phenomena of Latin culture, the social factors involved must be examined thoroughly in order to understand the exact nature of the problem under discussion. To assume that other women in the United States have not internalized the myths of patriarchy is to assume that Hispanic women are very different from other women in North America. I argue that this is not the case. The road towards female emancipation is a long one and 
women enter into it at many different points and at historically different times. A society that demands that both men and women work brings about the demise of patriarchy as a uniform ideology. Depending on what status a woman occupies in society at any given time will affect how she understands the world both from a traditional standpoint and from her present situation. To from new and more equitable ideologies for themselves is not only a task for Hispanic women but for all women as well. 


\section{CHAPTER II}

\section{THE BASIC PREMISES OF THE MARIA PARADOX}

\section{A. INTRODUCTION TO THE BOOK}

The Maria Paradox: How Latinas Can Merge Old World Traditions with New World Self-Esteem (1996) was written by Rosa Maria Gil, a New York psychotherapist and Carmen Inoa Vasquez, a New York Licensed Clinical Social Worker. The book is based on the belief that Hispanic women in the United States experience great difficulty in acculturating to the way of life of North America. The authors suggest that Hispanic women are caught between cultural expectations and "Americanized" values. Gil and Vasquez argue that only by raising self-esteem can Latinas acculturate successfully. In order to do so, Hispanic women must understand that they have been raised to be selfsacrificing and that if they continue to act in this fashion, they will not achieve success in the United States. Gil and Vasquez believe the Hispanic woman can bridge a gap between herself and "American" values to achieve empowerment. The differences that exist historically, linguistically, geographically, and politically among Hispanics are not acknowledged. Neither do Gil and Vasquez account for race, class or ethnicity as factors affecting the diverse experiences of Latin women. Rather, The Maria Paradox argues Hispanic women are victims of an ideology which they are responsible for internalizing and which they are responsible for changing.

To begin with, Gil and Vasquez explain that Hispanic cultural gender ideals, marianismo and machismo, hinder the acculturation process, binding "intelligent, 
ambitious Latinas to a no-win lifestyle" (1996:7). According to Gil and Vasquez the mental health of Hispanic women is related to their level of marianismo because marianismo can foster behavior that is detrimental to the mental and physical well-being of Hispanic women. Their purpose in writing the book was to help Hispanic women in North America to take a critical look at how they have been socialized, and to help them resolve the dilemma between "Old World norms and values and New World self-esteem." They believe that by raising their self-esteem Hispanic women can resolve their ambivalence and conflicts regarding women's issues in a way that would preserve valued Hispanic cultural ideals and traditions.

Gil and Vasquez argue that marianismo is a belief about the traditionally appropriate gender-role for women and which is complementary to machismo. Machismo, the other side of the coin, is the belief about the traditionally appropriate gender-role for men. They claim that while both ideologies may have worked in the "Old World," meaning that these role expectations were appropriate to the native country or cultural heritage of Hispanics, they are no longer appropriate, especially to life in North America. Most specifically, it is marianismo that is especially contradictory towards North American values.

\section{B. WHY THE PROBLEM EXISTS}

According to Gil and Vasquez, marianismo beliefs hinder the process of acculturation because self-sacrifice, passivity and submission to male authority are mandates of this gender ideology (1996:3). The clash, which Gil and Vasquez attribute to 
the acculturation process, is between a Latin woman's expectations for herself in the United States and what she has been taught by her native culture. On the individual level, these expectations range from a desire for a job, career or going back to school, to having power over her own life (Ibid:2-5). A woman who has power over her own life is not an ideal part of Hispanic tradition or culture (Ibid:5). According to Hispanic tradition, women are expected to "stay in place" and put the "husband's needs ahead of her own" (Ibid:8). Alongside these requirements is the expressly implied fact that women must marry (Ibid:49). These are some of the mandates of the marianismo ideology and it is precisely these mandates which are clashing with modern-day North American female expectations an ideals (Ibid:2-8).

\section{THE SOLUTION TO THE PROBLEM IS ROOTED IN UNDERSTANDING}

The empowerment is achieved when the Hispanic woman becomes "an independent-minded Latina" (Ibid:4). The authors believe that for most people, the previous statement is a paradox, a contradiction in terms (Ibid). Yet they also believe Hispanic women "can resolve in non-threatening ways the split between her family and community expectations and her own need and desires" (Ibid:3).

Gil and Vasquez state that understanding the problem is the way to resolve it. They see the "ambivalence and conflicts regarding women's issues" as experiehced by Hispanic females as rooted in three major sources: First by the traditional Hispanic gender 
roles of marianismo and machismo; second, the desire to acculturate or become a new member of a new culture, and last, the level of self-esteem a Hispanic woman has:

As you acculturate, your level of self-esteem can either make you or break you. If it's low, you stand a good chance of falling prey to marianismo/machismo and acculturation stress. If your self-esteem is high, you can conquer the pressures of tradition, and change to become a self-assured, socially and emotionally well-integrated North American Latina (Ibid:4-5).

Gil and Vasquez hope that the book will help the reader (the target market is Hispanic females or women involved in some way to Hispanics) to boost her self-esteem in the face of contradictory cultural and social pressures and learn to maintain a high self-esteem (Ibid:5).

\section{THE BASIC PREMISES}

According to Gil and Vasquez, the basic premises of The Maria Paradox is as follows: if a Hispanic woman's self-esteem is high, she will probably acculturate successfully and therefore have very few problems finding ways to meet her own needs and desires. However, if her self-esteem is low, she will suffer a cultural clash and accompanying acculturation stress because marianismo will only aggravate her adjustment to North American life (Ibid:5). This type of stress can then appear as a psychosomatic illness. Indeed, Gil and Vasquez claim that Hispanic women are at much greater health risk than non-Hispanics (Ibid:152-179). Marianismo is the culprit because it demands that women be subservient to men and that women are not capable of forging a life for 
themselves without their family's or their spouse's support. It breeds dependence and not independence and is not based on an ideology of individualism.

\section{E. THE HEALTH OF HISPANIC WOMEN}

The health of Hispanic women is tied to their desire to acculturate, their level of self-esteem and their degree of marianismo. They used the research of Escobar (1983) and Mezzich (1983), whose findings indicate that:

Latinas both here and in their native countries suffer from somatic disorders at a substantially higher rate than North American women (The Maria Paradox 1996:138).

Gil and Vasquez feel that the high incidence of emotionally connected complaints might be the result of marianista martyrdom, of self-denial and self-sacrificing behavior, thus supporting their belief that Latin women are less healthy overall than non-Latins (1996:138). Marianista sexual mandates, such as "sex is for making babies," cause Hispanic women to feel guilty and sad because they don't accept themselves as sexual beings (Ibid:139). This becomes a problem when Hispanic women want the same rights and privileges that The Maria Paradox claims American women demand for themselves, but don't want to be like American women because "to many Hispanics, then, an American female is una mujer liviana, a loose woman" (Ibid:132). In other words, Hispanic women don't want to be considered "loose" because that will guarantee their rejection by the Hispanic community.

In addition, they cite the work of psychologists Szapocznic and Kurtines (1980) who have found that Hispanics tend to develop self-esteem problems when they find it had 
to integrate two cultures (Maria Paradox 1996:22). Gil and Vasquez argue that Hispanic women want to have the freedom they perceive North American women as having but don't want to lose the respect of their family and friends by being seen as non-traditional or too forward and demanding (Ibid:44-47). They argue that this ambivalence causes some Latinas to have trouble taking action, and this lack of self-assertion is a significant component of self-esteem (Ibid:22).

Gil and Vasquez argue that traditional macho and marianista sexual mores contribute to putting Hispanic women more at risk for AIDS and other sexually transmitted diseases, simply because sexual empowerment is a marianismo taboo (Ibid: 144, 126-138).

\section{F. MACHISMO AND MARIANISMO ARE TWO SIDES OF THE SAME COIN}

According to Gil and Vasquez, their book presents the concept of marianismo to the general public for the first time. They learned of it from Evelyn P. Stevens (1973) who wrote academically about marianismo:

No self-denial is too great for the Latin-American woman but far from being an oppressive norm it has impetus from women themselves, and thus one can regard marianismo as part of a reciprocal arrangement, the other half of machismo [as quoted in The Maria Paradox (1996:6-7)].

Machismo is defined by De la Cancela (1986) as the socially learned and reinforced set of behavior in Latino society which men are expected to follow (Gil and Vasquez 1996:7). The dark side of machismo is that it dictates that the place of men is in the world, while 
woman's place is at the home. Men have options, women have duties (Ibid:5-7). However, Gil and Vasquez say there is a lighter side to machismo, because the man is also the gentleman, the protector of his wife and family (Ibid). They explain that the gentleman macho gives the best seat to the woman, opens doors, helps carry heavy packages, and does the heavy household chores (Ibid:5).

As a complement to machismo, marianismo holds antiquated cultural structures firmly in place and sits at the center of The Maria Paradox (Ibid:6). Gil and Vasquez believe that by presenting The Maria Paradox to the general public, they can help Hispanic women achieve the emancipation necessary to achieve success in the acculturation process.

\section{G. MARIANISMO IS PERFECTION}

For Gil and Vasquez, the ideology of marianismo is a role which takes as its model of perfection the Virgin Mary (1996:7). Marianismo is about being submissive, living in the shadows of men and male children, dispensing care and pleasure, literally and figuratively. They write that the woman who follows that belief can be called a "marianista..... and can be compared to a cloistered nun... her groom is not Christ but an all too human male who instantly becomes the single object of her devotion for a lifetime" (Ibid:7-9). Gil and Vasquez quite rightly ask the question, "what good could come from such a belief?" The authors feel that in the Old Country it gave women "a level of protection as a wife and mother, certain power and a great deal of respect" (Ibid:9). However, they insist that at present, marianismo results in a no-win situation because it 
dictates life in a "world that no longer exists and it perpetuates a value system that equates perfection with submission" (Ibid:7), that is the demanded female subjugation implicit in patriarchy.

Gil and Vasquez explain that marianismo has been taught from generation to generation by mothers and grandmothers, that it is indeed about female subservience, and that practicing marianismo leads one to feel more like a servant than a venerated woman (Ibid:6-8). They made a list of ten statements that they believe represent the mandates of the marianismo ideology, and refer to them as the Ten Commandments. Each mandate serves as a chapter title in the book. More importantly Gil and Vasquez write that each of these mandates conflicts with "economic needs and social and marital obligations" that Hispanic females face in North American society today (Ibid:8-9). They feel that the very actions appropriate to the marianismo mandates are in extreme contrast to the expectations of self-assertiveness, the latter of which is almost an expectation of women in North America at present.

\section{H. THE TEN COMMANDMENTS OF MARIANISMO}

Gil and Vasquez explain that the greater a Latin woman's conformity is to the norms, values and expectations of marianismo, the greater the community and family acceptance is of her. A woman's self-esteem is therefore directly related to the degree of her conformity to the "Ten Commandments":

1. Do not forget a woman's place. Essentially, a Latin woman must not forget the Latin family's and community's expectations of her, in spite of the fact that she 
may have new needs and desires not previously addressed. Gil and Vasquez use the expression "Old World versus New World" to refer to this social more (Ibid:1-19).

2. Do not forsake tradition. "Staying Latina rather than going Angla" is the way Gil and Vasquez explain that changing and conforming to American standards is threatening to the family. Any kind of emancipation is dreaded, from simply choosing to stay in school or follow a career rather than marry the socially approved fiancee, choosing to move to another city for career purposes, or choosing to cohabit rather than marry first. When the parents no longer have the ability to control the woman's choices, then confrontations occur. These confrontations are painful for Hispanics because part of Hispanic culture is unquestioning patriarchal dominance. The bulk of the vignettes show Latin women seeking help from Gil and Vasquez mainly due to these kinds of confrontations (Ibid:20-48).

3. Do not be single, self-supporting, or independent-minded. This mandate comes in when there is a war between "enforcing marianismo versus forging ahead with a personally satisfying lifestyle" (Ibid:49-76).

4. Do not put your own needs first. Gil and Vasquez use the expression "selflessness versus self-fullness." Having to juggle two value systems can wreak havoc. They argue that a woman who moves in with her parents because she is going through a divorce and has two children to support can be regarded as socially inadequate and incapable of taking care of herself, either by herself, because she has low self-esteem, or by others (Ibid:80). Gil and Vasquez say this causes stress to intensify and alienation occur. The woman may now experience self-doubt, which includes feelings of worthlessness and 
sadness. Because the Hispanic woman must "do for others no matter how great the sacrifice," her divorce is seen as a failure on her part. She is now in a no-win situation (Ibid:77-97).

5. Do not wish for more in life than being a housewife. The world of work belongs to the men, and the home and hearth are the woman's domain. Any deviation from that dictum is questioned, and any attempt to work at anything more than "pinmoney" status is a threat because the concern given to the world of work will now interfere with a woman's ability to manage the household (Ibid:98-125).

6. Do not forget that sex is for making babies - not for pleasure. Gil and Vasquez argue that sexuality in the Old World marriage of the mothers and grandmothers was an absolute duty, and therefore the new generation of women who expect pleasure to be a part of the sexual arena are considered unchaste, because it runs contrary to the mores of Hispanic tradition. To seek passion is to be Angla which is to be unchaste, to say the least. It is important to note that the authors of The Maria Paradox are not saying they consider these antiquated beliefs appropriate, sound or just, but simply that they exist, run counter to emancipation and female empowerment and lead to verbal and physical abuse, and alcohol or drug abuse (Ibid:126-151). Simply put, Gil and Vasquez are arguing that marianismo is codependency and dysfunctional and that any behavior on the part of a Hispanic woman that would be considered appropriate and healthy by feminist standards is considered inappropriate by Hispanic standards.

7. Do not be unhappy with your man or criticize him for infidelity or gambling. For Gil and Vasquez, Hispanic traditions says that once a woman chooses to 
marry, she stays put for life. In the face of those vices, the Hispanic woman is the "noble martyr" and it is the work of The Maria Paradox that will enable her to achieve selfsatisfaction and to become a "nueva marianista" (Ibid:152-179).

8. Do not ask for help. Gil and Vasquez argue that marianismo calls for a superhuman rather than a healthy human being (Ibid:180-203).

9. Do not discuss personal problems outside the home. A woman is to struggle alone as her ancestors did before her rather than trust strangers with an account of her situation. Any deviation from that, even joining a support group, may be considered threatening by the partner, simply because it implies that she is no longer willing to play the codependency game and will be seen by the native group as weak. She is weak because she is rocking the boat and changing herself. It is better to live isolated than to go to mental health experts for aid (Ibid:204-235).

10. Do not change those things which make you unhappy that you can realistically change. A Hispanic woman must go with the flow rather than make waves (Ibid:236-266).

Gil and Vasquez say that acting contrary to these mores would be considered appropriate and realistic in North America, but acting contrary to them will bring about negative sanctions from Hispanic family members and from the greater Hispanic community. They never use the words codependent or dysfunctional, but the contrast between what appears appropriate by Hispanic standards and what is healthy according to modern-day psychologists is the contrast between codependency and health. For example, throughout the book the case studies present problems stemming from each of the above 
mandates. The marianista is unhappy because she doesn't like the way her husband ignores her. She is indecisive. She doesn't know what to do to get him to change, so there is no resolution. She does not have the support of her husband, parents or children, because she is supposed to tolerate whatever behavior takes place without regard to herself. The marianista is to put everyone else's feelings and desires first. If she does indicate her dissatisfaction with her husband, then both he and family members reject her. This non-support appears in the form of frowns, long faces, withdrawal, insults and insinuations, including other forms of behavior which are used (obviously effectively) to bring the malfeasant back on track. In the worst case, verbal or physical abuse takes place, which created the "expected subservience" from the woman in question.

\section{ACCULTURATION IS BETTER}

Gil and Vasquez have used the definition of acculturation as it was given by Berry (1990): the gradual process whereby immigrants shift attitudes and behavior toward those of the dominant culture as a result of repeated exposure (Ibid:11-12). They emphasize that acculturation is positive: "the truth is we can't avoid the new culture if we want to survive and prosper." They explain acculturation as a process experienced as a series of changes and choices. However, Berry states that acculturation can be stressful and can lead to insecurity if traditional cultural patterns aren't useful in the new country (Maria Paradox 1996:12). For Gil and Vasquez, acculturation stress causes confusion and insecurity, simply because the process in not acknowledged as collective one, but is seen as the fault of the individual. Although they acknowledge that acculturation is a collective 
experience, they recommend alleviation of the stress of acculturation through such individual methods as the raising of a woman's self-esteem.

Gil and Vasquez believe Latin women view this process individually rather than collectively because they see the conflicts through the lens of marianismo (Ibid:12). Gil and Vasquez argue that Latinas end up feeling insecure, confused and guilty for straying from tradition because what they used to do to resolve the conflicts, which worked for the previous generations, isn't bringing about the previous results. Gil and Vasquez don't use the term sanctions but their explanations of the problems Hispanic women face seem to be more about acceptance or actual legitimization rather than because of what they chose to do. It almost seems as if the choices they need to make are right on track, but are simply not acceptable or legitimated under marianista standards, and therefore the women are negatively sanctioned.

Sociologically, we describe behaviors in terms of the positive and negative sanctions afforded to us for compliance or noncompliance to the norms of the group. The authors write that marianismo was functional and legitimately brought happiness and respect to the previous generations but is now a dysfunctional set of mores (Ibid:49-76). The Maria Paradox never uses the words sanctions, ideology, dysfunction, nor codependent, yet their explanation of the situation fits the use of this type of terminology.

Gil and Vasquez acknowledge that acculturation can be viewed by family and friends as an outright disregard for tradition and that the newly acculturated female is often seen as a traitor to the group, but without acculturation there is no success (Ibid:1112). It is possible that it is better for Gil and Vasquez to write in terms of acculturation 
because if they say that marianismo is dysfunctional and that marianistas are actually codependent, then the very community they are attempting to represent and write for and about will reject their work. Rather than say that the multiple roads leading toward female emancipation include non-codependent behavior, they say that disregarding tradition and helping herself to become independent is part of the acculturation process. Again, since when is emancipation acculturation?

\section{J. THE SOURCE OF SUCCESSFUL ACCULTURATION: SELF-ESTEEM}

For Gil and Vasquez self-esteem has everything to do with fulfilling cultural expectations. They argue that self-esteem is heightened by the positive acknowledgment of family and friends to cultural conformity, and conversely being dismissed as selfish or disrespectful when nonconformity occurs can and usually does lower self-esteem. They argue that self-esteem is the "ability to be authentic, to accept oneself as competent, successful, worthy, and self-loving" (Ibid:14-15). But according to Gil and Vasquez, Latinas living in the United States may need to reframe aspects of their worldview, attitudes, behaviors, and values in North American terms in order to maintain a healthy adjustment to their new culture with little or no harm to their self-esteem. That is

acculturation (Ibid:15). They argue that acculturation actually entails a foregoing of the mandates of marianismo beliefs and therefore results in the confusion and low self-esteem that many Hispanic women in their clientele face. 


\section{K. SUMMARY}

According the Gil and Vasquez, marianismo is the Latin cultural gender ideal for females and it is complementary to machismo. Machismo is the Latin cultural gender ideal for males. Both of these gender role ideals have positive and negative aspects. However, while marianismo worked for women in the Old Country, it is no longer appropriate to women living in the United States because it can cause low self-esteem. Marianismo results in low self-esteem in Latin women because it venerates female subjugation and passivity, which is in opposition to North American cultural female gender expectations.

In addition, marianismo beliefs will hinder the process of acculturation because a woman cannot be a submissive and passive marianista and successfully acculturate as an emancipated Latin-American female. The stress of acculturating can make a woman become more marianista than ever in an effort to succeed at acculturation. It is the belief of the authors that marianismo beliefs and behavior may be responsible for the high rate of sexually transmitted diseases among Hispanics, including other psychosomatic illnesses.

Gil and Vasquez feel that by raising self-esteem, Hispanic marianistas can acculturate and balance the traditions of their native culture with life in the United States. 


\section{CHAPTER III}

\section{A SOCIOLOGICAL CRITIOUE OF THE MARIA PARADOX}

\section{A. NEW ROLES FOR HISPANIC WOMEN}

Sociologists recognize that role conflict occurs when people occupy positions whose demands conflict. Sociologists also recognize that the rapid social changes which are creating new roles for men and women are calling into question previous myths held sacred under the ideology of patriarchy (Freeman 1989, Friedan 1983, Hochschild 1990, Stockard 1993). For the authors of The Maria Paradox, only Hispanic women are socialized under the strongest tenets of patriarchy, while North American women are emancipated and empowered. I contend that Hispanic women socialized under marianismo will find it very difficult to adjust to their roles as members of the paid labor force and as wives, mothers, homemakers and caretakers and that this is a problem for all women.

The marianista is not unlike other women in the United States who are facing the demands of working outside the home for pay and working in the home with little or no tangible reward. Hochschild (1990) examines what happens to women who are held responsible for operating in two separate spheres of activities simultaneously and who are expected to perform well in both. The woman Gil and Vasquez describe, raised under the doctrine of marianismo, is like other women in that, as a woman and as a member of the paid labor force she is expected to achieve competence and be assertive in the workplace (Chusmir 1990). The entrance of the female from the domestic sphere of 
activity into the instrumental sphere, in this case the paid employment labor force, and the effect of that change which post-industrialism fuels, cannot be underestimated (Chusmir 1990, Rosenberg 1992). In fact, when women's entry into the paid labor force was deemed non-reversible, the concept of androgyny appeared because previous gender-role norms found under patriarchy were no longer adequate or appropriate for both women and men (Bem \& Bem 1970, Chusmir 1990, Jagger \& Rothenberg 1984, Powell 1988, Sargent 1985, and Feminist Frameworks 1984:10-31).

The marianista as wife, mother, homemaker, and caretaker is like other women in that she now takes on a "double shift" (Hochschild 1990). Even when the woman attempts to change her role by asking her spouse to share equally in the running and upkeep of the home, Hochschild found that actually most men offered little help, and even that sorely lacked in equality (1990:188-203). Hochschild attributes this to "the weight of a contradiction between traditional ideology and modern circumstances" (Ibid:194). The marianista as wife is expected to honor certain traditions: she is expected to be a good wife in order that her husband accomplish his work, which is all-important and justifiable. She must run an impeccable household. The marianista, as a mother, is largely held responsible for the care and upbringing of her children. To the above we must add that she has other social obligations. She is also expected to help her own parents and his parents as needed, especially during their elder years. At this point it is possible that immigrant women face another burden, and that is that they may have been the cultural brokers of their family. Therefore, they may be relied upon more often and with more frequency than other women in their same set of circumstances. It is possible that 
immigrants whose extended family members reside in the same community, which may be the case in an enclave situation, actually have more demands placed on them because they are also acting as cultural mediators. However, this alone is not sufficient to argue that Hispanic women are unlike other women in the traditional expectations held for and about women.

\section{B. FAMILISMO}

While the authors of The Maria Paradox suggest that Hispanics are much more concerned with their families than other cultures, this indeed is not the case (Coontz 1992, Goode 1973, Stark 1994). Scholars argue that the concern with familial responsibility is more apparent in traditional communities where extended family arrangements are the norm (Goode 1973). According to Stark the notion of familismo, which describes the sense of duty and responsibility towards the extended family, can be misleading if not understood within a sociohistorical content. Stark (1994) and Goode (1973) found that the stereotype of Americans being colder and less friendlier while other cultural groups were warmer and friendlier actually resulted from misconceptions about living arrangements. It appears that whenever a cultural group enters the United States, part of becoming "Americanized" is moving out of an extended family household (Goode 1973). In fact, Goode claims that a sign of immigrant success is the formation of a nuclear household, and this pattern has been taking place for the past century.

Portes (1990) explained that it is not uncommon for children of immigrants to balance the socialization they receive from their parents with that learned from teachers, 
peers and other persons found within the larger society. Often the immigrant values are the same, but their outward expression differs. Sung (1985) writes that one of the most common problems facing Chinese immigrants is their cultural belief in respect for elders and male superiority. These values can be located on a continuum, because while the ideal value is common to almost every other ethnic group, what constitutes the appropriate expression of the value differs. For example, Sung found that among ChineseAmerican males, dominance and strength are exhibited through containing oneself and one's body, not through fighting, kicking, yelling or punching, such that Chinese boys on American playgrounds are taunted as sissies and cowards. Here we see where strength as a gender-role norm for the Chinese finds appropriate expression through bodily containment while for Americans it finds appropriate expression through physical and verbal aggression (Sung 1985).

The same holds true for the Amish. While they value hard work, family and honesty, they are a much-maligned group, because their attempt to maintain their Amish identity above that of American Citizen has led to them to distrust the United States government's ability to impose a way of life on them that is behaviorally inappropriate for them (Haviland 1993:32-33, Hostetler 1971).

\section{THE MARIANISTA AS WORKING WOMAN}

Gil and Vasquez' marianista is now a member of the paid labor force who returns from work to carpool, laundry, marketing, cooking, cleaning, child care, caretaking, and is supposed to be sexually ready and willing at bedtime. She has met everyone's needs, she 
has no limits, no boundaries. Is this woman Hispanic, or Asian, Black or White, or is she Muslim or Catholic or Hebrew? Actually, she could very well be any of these. In this way the Hispanic woman is not very different from other women in that women in general have been socialized under the control myths of patriarchy (Lipman-Blumen 1984). That women work is not new. What is new is that at no time in history have women been held responsible for their own success and failures as creatures separate and equal to men, even though the inequality in terms of opportunity, status, prestige and wealth continues. I argue that the woman Gil and Vasquez write about is not different from other women. In fact, it is precisely her immigrant status and her employment that have actually brought her closer to other women in terms of problems common to women in the United States in general.

According to scholars, the history of immigration in the United States indicates that for both political and economic reasons, immigrants cluster in enclaves (Parillo 1996, Portes 1990, Stark 1994). Portes and Parillo argue that the labels used in the United States, such as Hispanic, Asian, Pacific Islander, and Black to designate race and/or ethnicity are actually political terms which the dominant society uses as convenient cultural identity markers. While these labels are convenient they actually negate the differences found between and even among the individual groups in many ways.

For example, these labels do not differentiate the geographical, linguistic, religious or political differences that exist. "Hispanic" is an ethnic category based mainly on language and it lumps together millions of people of diverse geographic origin - Puerto Rico, Mexico, Cuba, Guatemala, whereas "Latino" is a broader category which can also 
include Brazilians, who speak Portuguese (Kottak 1996). While used for identification purposes, these terms are misleading. For most people, negotiating ethnic identity is variable because of such factors as the historical moment when emigration from the country of origin occurs and that at which the immigrants enters the United States (Parillo 1996, Portes 1990, Stark 1994). It is not unusual for immigrants to describe themselves as "Cuban or Mexican" amongst family and friends but consider themselves American when conducting business or dealing with the wider society.

The taking on of an ethnic identity and the use of ethnic/racial identities are often manipulated (whenever possible) for the well-being of the occupant (Portes 1990). In fact, ethnicity is a phenomena whose meaning is often imposed on the groups at one period of time depending on the political and economic consequences to the host country (Ibid). For example immigration is not a problem for the dominant society until the immigrant group is used as a scapegoat for problems in the economy (Portes 1990, Parillo 1994).

Portes explains that the farmers from Southern Italy who emigrated during the turn of the century due to famine discovered that they were "Italian" only after arrival in the United States. Prior to that, they saw themselves as farmers and had no nationalistic ties to the nation of Italy (Stark 1994:46-67, Healey 1995:121-134). I believe that Gil and Vasquez fail to mention that in all probability, the client who seeks help doesn't necessarily define herself as Hispanic, but rather sees herself as "Clara Rivas-Contreras from Santo Domingo." While Clara is a fictitious example, we know that her identity is undergoing a structurally and politically imposed change. However, Portes makes clear 
that the more visible the immigrant, the greater the imposition of identity from external circumstances.

Circumstances which lead to the creation of new identities occur through involvement within the educational, political, medical and economic institutions of postindustrial American society. Fluency in English is tantamount to "blending in" verses standing out, and in this sense are immigrants liable to vary cultural identity as the situation mitigates. Portes, Stark and Parillo argue that the existence of an enclave is tantamount to success in the United States because of the availability of networks. Another important aspect of immigration is the socioeconomic status of the immigrant. Speaking in terms of Hispanics, this usually depends on a woman's husband or father, usually because it is men who emigrate rather than single women (Portes 1984;1990). There is no country in Central or Latin America that has achieved equality between the sexes to the point where women act on par with men and separate from them. Therefore, we can assume that for Hispanic women, dependence on men has been the norm and the undertaking of new roles will forge new identities that will vary with the social context.

Race as a socially derived construct which Gil and Vasquez avoid. For example, a Portuguese-speaking Brazilian woman's racial identity in Brazil will not be the same as the one imposed on her in the United States (Healey 1995). Typically, she would be labeled according to definitions of race as determined historically and politically at the point in time of her entry (Portes 1984:1990, Parillo 1996). Puerto Ricans, although they are citizens of the United States, are a minority group. Gil and Vasquez don't consider this 
factor of any importance, even though their case study of Tina (Maria Paradox 1996:28-

43), a thirty year old Puerto Rican, is a classic example of reactive ethnicity.

Her father was a hardworking longshoreman who was seriously injured and unable to work; he became embittered and felt his misfortunes in America were solely due to his being Hispanic. Consequently he instilled an exaggerated sense of ethnicity in his children: "Papi told me that only Puerto Ricans are to be trusted and that I should only marry a man from there." Now she lives in the Barrio, and because she is the eldest daughter of five children, she needed to care for her father and was drowning in depression.

Gil and Vasquez failed to consider how structural factors such as her minority status and socioeconomic class adversely affected her ability to deal successfully with her father's disability. Instead they focused on her internalization of the patriarchal myths and seem to favor making her responsible for her family's dependence on her. Instead, they continue:

she was clinging to her marianismo even though women in her native country considered them outdated (p. 29). She was catering to her father's needs instead of her own and making sure she'd never meet an appropriate man because to her, all men wanted was to have sex, not to love or care, but she couldn't have sex because decent women were virgins until marriage.... She was refusing to acculturate or be self-reliant....As her depression grew she got smart and began therapy. She became aware that she alone was responsible for changing her overwhelming unhappiness ..... She was actually sabotaging her employment opportunities by showing up at interviews dressed inappropriately, or presenting herself such that she came across as inadequate. Some of the reasons she expressed for her difficulty in completing her degree were also complete distortions. In therapy, she learned that she was unconsciously afraid of being the only successful person in her family, which would jeopardize her fitting in. Once she realized that she had hidden behind the marianista tenet of self-sacrifice, the real Tina started to emerge. She dieted, joined a fitness class, got her nails done and went on 
vacation without her family. She found a satisfying job, married a Hispanic American, has two kids and is making sure they grow up with minimal guilt and pride in their Hispanic-American heritage (p. 43).

Gil and Vasquez fail to mention that Tina's internalization of the myths of patriarchy is quite common to women, depending on where they are in a continuum toward emancipation (Reinekee 1989, Sharma 1987). They failed to examine how her father's low socioeconomic status and growing dependence on her did not give her the skills and knowledge necessary to cope and even succeed in spite of her particular situation.

I believe the greatest flaw with The Maria Paradox is that it blames the Hispanic woman for internalizing the myths of marianismo, or rather the myths of patriarchy. The authors argue that Hispanic women have the power to change any overwhelming unhappiness, yet don't communicate how the social, political, and economic factors that patriarchy built helped the internalization of the marianismo myths.

\section{PATRIARCHY IS THE ISSUE NOT MARIANISMO}

Gil and Vasquez believe marianismo places Hispanic women more at risk for psychosomatic illnesses than other women in the United States because it demands that women be submissive, subservient, and act in deference to male authority. While they note that marianismo is connected to patriarchy and Catholicism, I argue that they fail to recognize the incredible influence of the Catholic church in perpetuating the belief that patriarchy as an ideology is benevolent and just. That Catholicism reigns unchallenged 
throughout most of Central and Latin America, with the exception of a few areas where indigenous peoples live, is no small matter. Anyone socialized under particularly strong tenets of patriarchy, be it Catholicism or Judaism and coming from a more traditional society is bound to experience a great deal of stress upon arrival in the United States, especially when they are exposed to opportunities which now exist for women here that may not have been available to them previously, like a low-cost community college.

The newly arrived Marianista, with her marianista beliefs tucked squarely under her arms (read patriarchy), so sure of herself and so trusting of her man's ability (read patriarchy) to make a good life for themselves in the land of opportunity (capitalism under patriarchy), suddenly finds that she has no clue as to how to operate in the new world (post-industrial America) and turns to therapy (the new religion).

Enter Gil and Vasquez, who say, "we know your discomfort, your pain." Your problem is about acculturation and we have an antidote. Raise your self-esteem. Let the Old Marianista become a New Marianista. Buy our book, go into therapy. Ethnicity is hot and politically correct and you, Hispanic Woman (yesterday she was Clara from Santo Domingo), can conquer the world...if you can make it here, you'll make it anywhere...and live happily ever after." Isn't that the way the story goes? Welcome to America, year 2000, post-industrial, post-modernist, post-patriarchy.

That Gil and Vasquez barely touch the surface of what constitutes a post-industrial society isn't surprising. The target market for their book is Hispanic females from the middle class who have access to and can afford therapy. If we use Lipman-Blumen's (1984) discussion of the control myths rather than Gil and Vasquez to tell Hispanic 
women that they need to fend for themselves because Catholicism never had their best interest at heart to begin with is to open a can of worms. As Lipman-Blumen writes, to uncloak "the best interests at heart" myth, which I believe is at the heart of Catholicism, is perilous at best because it arouses widespread anxiety among rulers and ruled alike (1984:96). The Maria Paradox fails to recognize that what they believe is a problem of being Latin and female is actually a problem of being female in the United States. The claim that socialization takes place uniformly amongst women in North America is unfounded (Bem and Bem 1970,1984). What is common to most women in the United States at the present is that they are held responsible for their careers and for their children and their households equally (Scott 1984). This impossible standard is unrealistic and creates undue stress for women today. We make our way in a society that no longer offers an ideology to which there is uniform compliance. Therefore, it is my thesis that there is a historical continuum of change away from traditional beliefs, and towards a new type of society that demands we make choices without a perennial worldview that will validate them. This is not a very comfortable place for humans to be.

Patriarchy operates in the gender roles appropriate to the sexes. The Maria Paradox recognizes this. However, the stress of acculturation because of marianismo is actually a much greater event with far-reaching implications. It is my belief that both men and women in the United States, in relation to our position in the social structure, and in relation to the degree that we have internalized the myths of patriarchy, will struggle when we discover that the myths that explain the world are no longer appropriate. To believe that they worked in the Old World Once Upon a Time, as Gil and Vasquez argue in their 
book, is to believe that men have women's best interests at heart and women can trust men to protect their welfare (Lipman-Blumen 1984:92). To perpetuate that myth, as I believe Gil and Vasquez do, is much more comfortable than viewing traditional gender images as a series of control myths to perpetuate a patriarchal social structure which some could well view as "cultural male misogyny" (Ibid:93).

The Maria Paradox does not tell the Nueva Marianista (in the process of becoming because she now has a tool - the book) that perhaps the past patriarchal myths that were embroidered into Catholicism were man-made and quite possibly based upon male self-interest. Perhaps a better way of looking at marianismo would be to examine it using Lipman-Blumen's control myths (1984:69-98).

\section{E. WHY NOT SELF-ESTEEM?}

I believe The Maria Paradox's emphasize on self-esteem is actually detrimental to helping Hispanic women feel better about themselves in a new cultural context. I believe Hispanic women who become aware of gender inequality have every reason to be unhappy and understanding how the wider society and structural factors either help or hinder her individual life is an experiential part of human life.

Why don't Gil and Vasquez treat the implications of those psychosomatic illnesses, as Rosewater (1984) suggests. If a woman is diagnosed as depressed why not take a feminist approach and view it as originating from women's role in society? In fact, a feminist treatment of depression centers on an examination of the environmental impact on the woman, both historically and currently (Ibid). In addition, depression can be viewed 
as a coping skill or healthy reaction to an unjust situation (Paludi 1992:87-118, Rosewater

1984:272-3). Is it because that is too dangerous a place for a therapist to go when the newly arrived client is sitting before her with a crucifix in her hand?

\section{F. DID MARIANISMO EVER REALLY WORK?}

Gil and Vasquez don't acknowledge that female passivity and subservience and therefore marianismo could have been just as dysfunctional for women in the Old Country as they perceive it is for Hispanic women in the United States at present. However, their own case studies indicate that once their clients achieved a more honest dialogue with their mothers and grandmothers, the previous generations of women admitted to not being very happy or satisfied with past and the lack of appropriate choices available to them (see the case of Zulma on p.53, also pp.63-70).

They argue that because the agents of socialization passed down those myths, that those same women achieved success under them. Stevens is quoted in The Maria Paradox as writing:

No self-denial is too great for the Latin-American woman...but far from being an oppressive norm dictated by tyrannical males, marianismo has received considerable impetus from the women themselves.... it is possible to regard marianismo as a reciprocal arrangement, the other half of machismo (The Maria Paradox 1996:7).

Both Stevens and Gil and Vasquez fail to recognize that control myths are regenerated through generations of women, not because they experienced success under its tenets, but because that was the only available avenue toward acceptance within the social structure. 
We now make our way in a society that no longer offers an ideology to which there is uniform compliance. Therefore, there is a historical continuum of change away from traditional beliefs, and towards a new type of society that demands we make choices without a perennial worldview that will validate them. This is not a very comfortable place for humans to be.

The belief in female subservience is not unique to Hispanics and neither is the concept of machismo. Even when machismo is not the gender ideal, cross-cultural evidence shows that gender roles are very different from each other, with males in positions of power and authority (Gilmore 1990). Gilmore writes about what constitutes manhood in countries such as India, Iran, China, Egypt and Italy, and the common thread is the dominance of the male and the superiority of male activities $(1943,1990)$. What varies from place to place is the actual expression of male superiority, but not the idea itself. Therefore, patriarchy as an ideology is uniform, but the socially appropriate way of expression varies cross-culturally.

\section{G. CONCLUSION}

The Maria Paradox is a book about how Hispanic women can empower themselves through the recognition of an ideology that hinders empowerment: marianismo. However, Gil and Vasquez incorrectly blame Hispanic women for internalizing the marianismo myths. While they contend that the power to change is within the individual woman, they in turn place blame for the lack of change on her. This argument does not allow the recognition of how societal factors influence the 
internalization of marianismo, nor does it allow for the fact that marianismo is a part of the ideology of patriarchy and that it has been affecting women historically for hundreds of years.

It is fortunate for people that the belief in patriarchy is changing not only in the United States, but in most of the world. The subservience of females often no longer suits the rapidly changing societal conditions. The ideology of women's inferior status is daily being challenged. The demise of the control myths of patriarchy that Lipman-Blumen describes is taking place both on the individual psychological level and at the level of society as Betty Friedan and Gloria Steinem have described. The demand for labor in post-industrial society now places women in the instrumental and the domestic sphere of activity. The duality of this condition has created what many have argued as the double burden for women: they must work for pay and be the homemakers, wives and mothers that their mothers were thought of as being. Again, another myth is broken.

When structural changes occur - changes that don't perpetuate patriarchy (women in the paid work force, women as breadwinners, women as single heads-of-households) then women trying to follow any ideology of female submission and passivity will most likely suffer a great deal of psychological and socially induced stress.

Over half of all women work, and children are now taught that males and females are both able to contribute to society, that one is not more valuable than the other. Competence and assertiveness are essential elements to possess in the workforce. Once these traits become part of a woman's employment experience, how comfortable can she feel putting aside the feeling of power and independence that comes from being 
responsible for oneself (see Gloria Steinem's The Revolution from Within) to play a traditional subservient role with her spouse or other significant males within her native social sphere?

Gil and Vasquez' account of their largely Hispanic female clientele recounts frustration, resentment and confusion because they have been socialized (albeit under marianismo). How their client were taught to behave, think and feel are no longer appropriate for dealing with the diversity of experience and opportunities available in the United States. Marianismo no longer serves to perpetuate a woman's happiness but rather her growing unhappiness. Marianismo doesn't teach a woman how to ask for a raise, how to juggle demands, how to make choices without feeling resentment towards others because her own needs are not being met. Marianismo tells a woman she has no boundaries. Her time belongs to her family and her family's need come before hers. However, there is little evidence that females are socialized on equal terms with males at the present time. In this way, The Maria Paradox is flawed in assuming that females who are native to North America are socialized to be empowered and emancipated.

The extent to which patriarchy is being evaluated and more equitable ideologies are arising is part and parcel of post-industrial society and the growing roles for men and women. These new ideologies arise because the skills needed for meeting the demands of daily modern life did not occur until very recently.

The Maria Paradox fails to acknowledge the powerful influence of religious beliefs on gender stereotypes. The book also fails to recognize Catholicism as a form of social control and one that was not especially benevolent or caring of women. The ideology of 
marianismo isn't unique to Hispanics or any category of women simply because the ideology of patriarchal myths that bind women can be seen as a shared experience among all women. They fail to tell Tina that the social milieu that patriarchy built and that affects her is in large part outside of her control. 


\section{REFERENCES}

Alba, Richard 1985 Italian-Americans: Into the Twilight of Ethnicity. Englewood Cliffs, NJ: Prentice-Hall.

Bem, Daryle, \& Bem, Sandra S. 1970 "Case Study of a Nonconscious Ideology: Teaching the Woman to Know Her Place." In Beliefs, Attitudes and Human Affairs, Daryl Bem, ed. Monterey, Ca: Brooks/Cole.

Bem, Sandra L. and Bem, Daryl J. 1984 "Homogenizing the American Woman: The Power of an Unconscious Ideology," in Feminist Frameworks, by Alison M. Jaggar and Paula S. Rothenberg. New York: McGraw-Hill.

Blau, Francine D. and Winkler, Anne E. 1989 "Women in the Labor Force: An Overview." In Feminist Frameworks, by Alison M. Jaggar, Paula S. Rothenberg, eds. New York: McGraw-Hill.

Caplan, Paula J. 1985 The Myth of Women's Masochism. New York: EP Dutton.

Chusmir, Leonard 1990 "Myths and Realities Regarding Women." Lecture given at Florida International University, January 5, 1989.

Coontz, Stephanie and Peta Henderson 1992 (Eds.) Women's Work, Men's Property: The Origins of Gender and Class. London: Verso.

De la Cancela, V. 1986 "A Critical Analysis of Puerto Rican Machismo: Implications for Clinical Practice," Psychotherapy, Vol. 23, No. 2 (Summer 1986).

Escobar, J. I., Gomez, J., and Tuasson, V. B. 1983 "Depressive Phenomenology in North and South American Patients," American Journal of Psychiatry. 40:4751.

Fernandez-Kelly, M. Patricia and Anna M. Garcia 1990 "Power Surrendered, Power Restored: the Politics of Work and Family Among Hispanic Garment Workers in California and Florida." In Women, Politics and Change, Loise Tilly and Patricia Gurin, eds. New York: Russell Sage Foundation, pp.130-149.

Freeman, Jo 1989 Women: A Feminist Perspective. California: Mayfield Publishing Company.

Friedan, Betty 1983 The Feminine Mystique. New York: Dell Publishing.

Friedl, Ernestine. 1978 "Society and Sex Roles," In The Human Portrait, Michael B. Whiteford and John Friedl. New Jersey: Prentice Hall.

Gil, Rosa Maria and Vasquez, Carmen Inoa. 1996 The Maria Paradox: How Latinas Can Merge Old World Traditions New World Self-Esteem. New York: GP Putnam's Sons.

Gilmore, David D. 1990 Manhood in the Making: Cultural Concepts of Masculinity. New York: Yale University Press. 
Goode, W.J. 1971 "World revolution and family patterns." Journal of Marriage and the Family. 33:624-635.

Haviland, William A. 1993 Cultural Anthropology. Texas: Harcourt Brace Jovanovich. Healey, Joseph F. 1995 Race, Ethnicity, Gender and Class: The Sociology of Group Conflict and Change. California: Pine Forge Press.

Hochschild, Arlie 1990 The Second Shift. New York: Avon Books.

Hostetler, John and Gertrude 1971 Children In Amish Society. New York: Holt, Rinehart and Winston.

Kottak, Conrad Phillip 1994 Anthropology: The Exploration of Human Diversity. New York: McGraw-Hill, Inc.

Lee, Richard B. 1979 The !Kung San: Men, Women and Work in a Foraging Society. Cambridge, England: Cambridge University Press.

Lipman-Blumen, Jean 1984 "The Pentimento of Ancient Images and Contemporary Control Myths." In Gender Roles and Power. Englewood Cliffs, New Jersey: Prentice Hall.

Malinowski, Bronislaw 1926 Myth in Primitive Psychology. London: Routledge \& Kegan Paul.

Malinowski, Bronislaw 1948 Magic, Science and Religion and Other Essays. Glencoe, Ill: Free Press.

Mezzich, J. E., and Raab, E.S. 1983 "Depressive Symptomatology Across the Americas," in Archives of General Psychiatry. 37:818-23.

Nanda, Serena 1992 "Arranging a Marriage in India." In The Naked Anthropologist: Tales from Around the World, Philip R. DeVita, ed. Belmont, California: Wadsworth.

Parillo, Vincent 1994 Stranger to These Shores. 4th Edition. New York: Macmillan.

Parillo, Vincent 1996 Diversity in America. California: Pine Forge Press.

Paludi, Michele A. 1992 The Psychology of Women. Brown and Benchmark.

Portes, Alejandro 1984 "The rise of ethnicity: Determinants of ethnic perceptions among Cuban exiles in the US" American Sociological Review. 49 (June):383-97. and Ruben G. Rumbaut 1990 Immigrant America. Berkeley: University of California Press.

Portes, Alejandro and Robert L. Bach 1985 Latin Journey: Cuban and Mexican Immigrants in the US Los Angeles: University of California Press.

Powell, G.N. 1988 Men and Women in Management. California: Sage Publications.

Reinekee, Martha 1989 "Out of Order: A Critical Perspective on Women in Religion." In Women: A Feminist Perspective, Jo Freeman, ed. 
Rosenberg, Rosalind 1992 Divided Lives: American Women in the Twentieth Century. New York: Hill and Wang.

Rosewater, L. B. 1984 "Feminist Therapy: Implications for Practitioner." In Women and Mental Health Policy, L. Walker, ed. Beverly Hills: Sage.

Sargent, Alice G. 1985 Beyond Sex Roles. 2nd Edition.. Minnesota: West Publishing.

Scott, Ann Crittenden 1984 "The Value of Housework." In Feminist Frameworks, Alison M. Jaggar, Paula S. Rothenberg, eds. New York: McGraw-Hill.

Sharma, Arvind 1987 Women in World Religions. Albany: State University of New York Press.

Stark, Rodney 1992 Sociology. 4th Edition. California: Wadsworth.

Steinem, Gloria 1983 Outrageous Acts and Everyday Rebellion. New York: Holt, Rinehart and Winston.

Steinem, Gloria 1993 Revolution From Within: A Book of Self-Esteem. Boston: Little, Brown and Company.

Stevens, Evelyn D. 1973 "Marianismo: The Other Face of Machismo in Latin America," in Female and Male in Latin America, A. Decastello, ed. Pittsburgh: University of Pittsburgh Press.

Sung, Betty Lee 1985 "Bicultural Conflict." in Annual Editions: Anthropology 95/96. Guilford, Connecticut: Dushkin Publishing Group.

Stockard, Jean and Miriam M. Johnson 1992 Sex and Gender in Society. New Jersey: Prentice Hall.

Szapocznic, Jose and William Kurtines 1980 "Acculturation, Biculturalism, and Adjustment among Cuban Americans," in Acculturation: Theory, Models and Some New Findings, A. M. Padilla, ed. Boulder, Co.: Westview. 